\title{
From the 'mad' poet to the 'embodied' poet: Reconceptualising creativity through cognitive science paradigms
}

\begin{abstract}
Written by the author of three collections of poetry, this paper contests the enduring stereotype of the 'mad' poet, present in Romantic, psychoanalytic and psychological theories of creativity. Mobilising theories of embodied cognition, it offers a demystified and de-pathologised vision of poiesis and poetry. The paper focuses on three traits typically associated with the 'mad' poet in popular representations and theoretical understandings of that figure: extreme emotionality; divergent thinking; and a tortured unconscious. Using findings in the cognitive sciences, the essay demonstrates how emotional experience, divergent thinking, and the unconscious are integral parts of brain functioning, rather than traits exclusive to psychopathology. Poiesis is not informed, in any essential way, by madness but rather by the normal conditions of embodied cognition.

Keywords: theorising creativity, poetry, science
\end{abstract}

\section{Introduction}

The image of the mad poet is a commanding one in our cultural imaginary. According to that trope, the poet writes in a maniacal state and with a daemonic automatism. The poetry itself is akin to a perverted form of language, expressive of a perverted character. Think of Jack Torrance, as played by Jack Nicholson, in Stanley Kubrick's The Shining. While Torrance is ostensibly a novelist, in his deranged state of mind he repetitively types a single line of uncanny verse: 'All work and no play makes Jack a dull boy.' The mad poet is alternatively driven by emotional pain or disturbance. Rolf de Heer's film Bad Boy Bubby depicts the apotheosis of a mad poet from a traumatic childhood. In one scene the thirty-five-year old Bubby, performed by Nicholas Hope (looking eerily like Nicholson in The Shining), begins spontaneously reciting sadistic phrases remembered from his upbringing, which are interpreted as poetry by an audience at a pub. Roy Porter argues that poets and madmen 'stand out because of their strange speech' (Porter 1987: 262). It seems that the ramblings of a madman and the lines of a poet can be easily mistaken.

The figure of the mad poet, as Frederick Burwick helpfully documents in Poetic Madness and the Romantic Imagination, has a 'venerable' cultural history in the West, extending from ancient Greece to the modern day (Burwick 
1996: 3). As Burwick reminds us, the first critics of Western literature theorised from a Dionysian heritage, according to which madness was associated with divine intercession: Plato's Phaedrus claimed that in "vain does one knock at the gates of poetry with a sane mind"', while Aristotle's Poetics asserted that poetry " "demands a man with a special gift ... or a touch of madness"' (3). Against the Apollonian movement of the Enlightenment, 'the century-old notion of the furor poeticus' was rehabilitated by the Romantic poets including the archetypal 'mad poets' William Blake and Samuel Taylor Coleridge - 'as a revolutionary and liberating madness that could free the imagination' (Burwick 1996: 2).

Burwick himself firmly upholds a Romantic vision of poiesis, maintaining that 'madness is simultaneous with creativity' (Burwick 1996: 17). He portrays the poet as a kind of martyr, courageously exploring 'a dark side of the mind that is as intimate as the shadows of our own repressed consciousness' (275). The implicit reference to the unconscious is significant. As Albert Rothenberg observes, psychoanalytic understandings of creativity - whether they theorise creativity as a symptom of the Freudian repressed or as a manifestation of Jungian archetypes buried deep in the mind - have become thoroughly 'ingrained' in thinking about the creative process (Rothenberg 1990: 48). Given that psychoanalysis emerged from Romanticism's obsession with the irrational, it is hardly surprising, as Rothenberg notes, that the psychoanalytic belief in 'the unconscious creative wellspring' remains 'closely allied to allegations about a connection between creativity and madness' (48).

Empirically based psychological studies of creativity - which originate with Cesare Lombroso's The Man of Genius (1984 [1895]) (a phrenological study attributing 'genius' to hereditary insanity) and which currently make up a burgeoning field - also often endorse the link between creativity and madness. In Creativity and Mental Illness, Simon Kyaga outlines no less than 98 contemporary studies that explore the connection between creativity and psychopathology (Kyaga 2015: 107). He concludes that a consensus exists among these studies in regards to a connection between mood disorders, in particular, and creativity (146). In Affective Disorder and the Writing Life: The Melancholic Muse, Stephanie Stone Horton focuses on a study of University of Iowa workshop participants, which found that $80 \%$ of the students suffered from an emotional condition (Horton 2014: 2). Describing her own experience of manic depression, and evoking Sylvia Plath - another of the quintessential mythic mad poets - Horton contends that 'writing is like opening a vein' (3). In Strong Imagination: Madness, Creativity and Human Nature, Daniel Nettle delineates various 'statistical studies of the association between psychotic and creative traits' (Nettle 2001: 141) to support his Darwinian thesis that madness has persisted in our genome because it underlies 'one of the things that we as humans most value, namely enhanced creativity' (187).

There are a number of reasons to be suspicious of scholarship strongly correlating creativity with psychopathology. For one, there is the reification and at times romanticisation of madness that characterise many of these accounts. As Burwick himself acknowledges, following the work of Michel Foucault, madness is a historical construct, which is 'renegotiated from age to age as norms change and tolerance for aberration waxes and wanes' (Burwick 1996: 3). In Madness and Civilization: A History of Madness in the Age of Reason, Foucault traces the origin of clinical diagnoses of madness to the Enlightenment, showing how 'reason' and 'unreason' were ideologically defined. Indeed, the emerging middle-class valorisation of industry and capital meant that poverty and idleness could justify institutionalisation in Europe's newly established houses of confinement. Foucault demonstrates how diagnoses of madness 'did not proceed from observation to the construction of 
explanatory images ... on the contrary, the images assured the initial role of synthesis ... their organizing force made possible a structure of perception'

(Foucault 1989 [1961]: 128). In other words, socio-politically constructed traits of madness defined the condition of madness. Madness remained firmly defined in socio-political terms when it was redeemed after the Revolution, during which 'alienation' from civilisation came to be deemed a virtue (209). [1]

Psychopathology continues to be defined in reified ways despite also continuing to display historical contingency. Kyaga, for instance, notes that the two diagnostic systems used to classify disorders in contemporary psychology, the International Statistical Classification of Diseases and Related Health Problems and the Diagnostic and Statistical Manual of Mental Disorders, are 'continuously updated' (Kyaga 2015: 7). According to Judith Schlesinger, recent times have seen a 'lowering' of 'diagnostic thresholds' in the Diagnostic and Statistical Manual of Mental Disorders in ways that 'sweep even more normal people over the doorway into pathology' (Schlesinger 2014: 62). She argues that a psychopathological condition such as bipolar disorder commonly associated with creativity in recent studies - 'has gradually become so elastic, with so many possible levels and gradations, that it captures virtually anyone who's ever had a mood' (62). There have also been 'abrupt spikes' in disorders such as Attention Deficit Disorder and Autism that have aroused suspicion regarding the relationship between psychotherapists and drug companies (62). It seems that normality, in a climate in which psychotherapists and drug companies stand to gain from abnormality, is hard to achieve.

The phenomenon of creativity, like that of madness, is similarly vulnerable to reification, while also demonstrating historical variability. As Schlesinger notes, contemporary studies of creativity in psychology, which consider diverse manifestations of creativity from the scientific achievements of Nobel Laureates to the symphonies of Beethoven, tend to 'condense creativity into a single, powerful force, which helps underscore its similarity to madness' (Schlesinger 2014: 63). For Schlesinger, 'forging a scientific link' between creativity and madness 'is like trying to get two clouds to stick together' (64).

In psychological studies of creativity that are specifically focused on writers, as Schlesinger also outlines, the findings are consistently compromised. They often involve a selective focus on the sensationally suicidal and on retrospective diagnoses of madness. The methodology of such researchers, according to Schlesinger, involves little more than 'gathering up the few facts they can find, and using their imagination to fill in the rest' (69). In regards to the often-cited longitudinal study of Iowa Writers' Workshop participants, Schlesinger reveals that the study sampled only 30 people and relied on the researcher's diagnosis of traits representative of psychopathology (66).

Schlesinger also notes the ways in which the cultural stereotype of the mad poet, a 'glamorous cultural icon' following the Romantic period, inexorably informs the ways in which writers - from students to the famous - envision themselves (68). In Inspiration: Bacchus and the Cultural History of a Creation Myth, John Moffitt interrogates the Dionysian self-styling of writers and artists across the ages. In fact, he argues that art itself - from Michelangelo's sculpture of Bacchus to André Breton's conceptualisation of the unconsciously inspired writer - is often employed to affirm the image of the enraptured artist. The installation of the figure 'artist-priest-prophet' (Moffitt 2005: 258), Moffitt writes, comes with 'a complementary syndrome, "Art-Worship"” (267).

Timothy Clark similarly considers the account of the ecstatic writer as strategic, but he also suggests that it is informed by an internalisation of the 
reader's enraptured experience before a text: 'a writer's conception of a "creative" "inner" power is often an image of an anticipated rhetorical effect' (T Clark 1997: 10). Clark also takes seriously the feeling of a 'hiatus in the structure of subjectivity' - the sense of self-alienation - that writers often report experiencing as a characteristic of their creative praxis (19). However, rather than attributing this to madness, he ascribes the poet's sensation that 'meaning is always elsewhere' to the humble fact of 'self-reading' (19). Clark, who describes composition as 'improvised performance mediated by selfreading' (15), explains how the writing 'is no sooner written than read' so that it almost immediately begins 'diverging from what may have been intended, suggesting unexpected directions for the text' (19). Clark also considers the compelling influence of other texts and cultural patterns of meaning, as well as the generative power of formal elements such as rhyme and rhythm. In other words, for Clark, mad poiesis "is a "textual effect"” (26). A poem is generated by the conventional power of language and by its inevitable intertexts.

Similarly highlighting the disciplinary context for poiesis, Rothenberg lays stress on the neglected but significant role of revision. With its requirement of cultured intellection and temporal commitment, revision is a process antithetical to the furor poeticus. Conceiving of 'good poems' as 'arduously achieved' (Rothenberg 1990: 40), Rothenberg invokes his own research of successful writers which reveals only the common personality trait of 'motivation' (1990: 8). For Schlesinger, Rothenberg's study has a greater claim to legitimacy than many others, being conducted by a Harvard psychiatrist (Rothenberg himself) and his team over the course of 25 years, and having involved more than 2000 hours of interviews conducted by Rothenberg personally (Schlesinger 2014: 66). Rothenberg's ultimate conclusion is that creative processes are 'healthy ones' (Rothenberg 1990: 36).

Notwithstanding the inevitability that some writers of poetry do suffer from mental illness - just like some bakers or carpenters, albeit without the cultural glory - this paper extends Rothenberg's vision of poiesis as an activity resulting from perfectly normal processes of cognition. There is simply no need for madness to enter the creative situation. In order to arrive at a depathologised and demystified understanding of poetic praxis, I will focus on a specific manifestation of creativity: poiesis. Like Clark and Rothenberg, I will also take into account the cultural context and technical work informing poiesis. However, my ultimate focus will be on findings from the cognitive sciences. Cognitive science shows us how to reconsider creativity as a natural function of the embodied mind rather than as a practice symptomatic of psychopathology.

This paper attends specifically to three traits typically associated with mad poiesis: emotional extremity; divergent thinking; and unconscious processes. These characteristics are apparent in the cultural images of the mad poet with which this paper began, inevitably informed by ancient and contemporary Romantic, psychological and psychoanalytic - theories of the creative process. [2] The intention of this paper is not to undermine the significance of those traits to poetic praxis. After all, writing poetry is often experienced as an emotional practice, as the tradition of teen-angst poetry demonstrates; it can involve divergent perception, as the Russian formalists suggested when theorising de-familiarisation as central to poiesis; and it can feel as if unconscious forces uncannily inform the writing, as Freud famously hypothesised. Certainly, as the author of three collections of poetry, I can relate to such sensations. However, this paper will argue that experiences of emotionality, innovative ideation, and unconscious 'forces' can be viewed as intrinsic not to madness but to healthy processes of embodied cognition, according to which feeling, flexible thinking, and the unconscious are 
functionally necessary. As Francisco Varela, Evan Thompson and Eleanor Rosch argue in The Embodied Mind: Cognitive Science and Human Experience, 'living cognition' is 'creative cognition' (Varela, Thompson \& Rosch 1987: 145 \& 148). Poiesis, this paper contends, speaks fundamentally of that creative cognition, rather than of a disturbed state of mind.

\section{Emotional cognition}

The first characteristic of the furor poeticus that I will re-examine with the help of cognitive science is emotionality. Alice Flaherty's The Midnight Disease: The Drive to Write, Writers' Block, and the Creative Brain (2005) is one of a recent spate of psychological studies that not only reaffirms the ancient myth of the mad poet but that is especially attentive to the emotionality of creative praxis. Flaherty argues that 'creativity has been more closely linked to mood instability than to cognitive traits such as high IQ' and cites research suggesting that poets are forty times more likely than the general population to suffer affective disorders such as manic depression (Flaherty 2005: 33). In a lamentably reductive reading informed by her vision of creativity as emotional illness, she goes on to read Plath's Ariel as 'a poem cycle about PMS' (132). Advocating what she calls a 'need theory of self-expression,' Flaherty proposes that creative writing is informed by 'an abstracted version of the same biological urge that causes you to cry out in sorrow or anger' (203). Poiesis is thus configured as an unmediated expression of feeling, which is effectively synonymous with dysfunction.

Schlesinger's concerns about 'empirical' studies of madness and creativity, such as those relied upon by Flaherty, are worth keeping in mind. It is also the case that Flaherty's definition of writing as the expression of feeling occludes any notion of artistry. She also, in a gesture typical of psychological studies of creativity, ignores a vast literature by healthy poets. However, the idea that poetry involves emotional expression is not unreasonable. What is problematic is the way in which affectivity is unnecessarily conflated with pathology. Emotionality is not a disorder. Emotion is not even irrational. Cognitive science, as this section of the paper elucidates, has rehabilitated emotion as an essential dimension of both cognition and language use.

While older computational models of the brain tended to emphasise the rational work of the cerebral cortex, contemporary theories acknowledge emotion as vital to cognition. As Paul Armstrong explains, the brain is made up of 'two systems ... that are the result of different periods of evolutionary history - the brain stem, which regulates basic bodily functions and is the source of "primordial feelings," and the cerebral cortex, where higher-level activity (both emotional and cognitive) occurs' (Armstrong 2013: 121). The brain stem's emotional processes of cognition are more primary and occur more rapidly than cerebral processes. The reasons behind this draw attention to the mind's embodiment. It is often said that we are 'moved' by an emotional scene, and in fact emotion literally 'moves' a body, generating hormones that trigger what feel like spontaneous reactions. For example, a stick in the grass might be emotionally perceived as a snake, with adrenalin released to facilitate movement away from the scene. Milliseconds later, processing in the cerebral cortex reveals the error. However, even this higher form of cognition is hardly free of emotion and motion. The cognitive shift is marked by a feeling of relief and a simultaneous movement involving relaxation. Thus emotion, as Armstrong argues above, remains at work even in 'higher' cognition. 
This example demonstrates how the embodied brain is primarily oriented towards perception and movement, with emotion functioning to integrate perception and movement. Antonio Damasio, a neuroscientist who has undertaken significant research into the connection between embodied cognition and creativity, observes how feeling attends every perception and how we are continually 'moved' by our cognisance. He describes embodied cognition as dynamically emotional, arguing that no

set of conscious images of any kind and on any topic ever fails to be accompanied by an obedient choir of emotions and consequent feelings. As I am looking at the Pacific Ocean dressed in its morning suit, protected by a soft, grey sky, I am not just seeing, I am also emoting to this majestic beauty and feeling a whole array of psychological changes that translate, now that you ask, into a quiet state of well-being. (Damasio 2012: 254)

Notably, his language is poetic - and, for Damasio, feeling is indeed central to the arts. In fact, Damasio argues that emotion is central to the experience of subjectivity that gives rise to the arts, which is to say that it is integral to our identities as conscious beings. Damasio writes that while feeling may not be something we can always consciously control - a fact that only underlies its importance to human survival - it is 'the basis for the conscious you' (172). Thus the sensation of the body being powerfully moved in response to stimuli is conceived not as a symptom of madness, but as fundamental to the sense that we exist. As Damasio puts it, revising the ratiocentric maxim of René Descartes, it is not that 'I think, therefore I am'; it is that 'I feel, therefore I am.'

Emotion is also essential to the tool of language. As Jerome Feldman writes in From Molecule to Metaphor: A Neural Theory of Language, while language can often be 'treated as an abstract symbol system,' it is 'crucially shaped by the properties of our bodies' (Feldman 2006: xii \& 7). Language, in fact, has its roots in our embodiment; in our integrated perceptual, emotional, and motility systems. This is evident in the fact that our perception of words moves us, quite literally. Brain scans have confirmed, for instance, how reading the word 'kick' activates areas of the brain associated with motor activity, triggering feelings of movement (Glenberg 2008: 47).

Various studies have accentuated the importance of expressive movement to language. Maurice Merleau-Ponty's ground-breaking work in embodied cognition, for instance, describes how an infant initially experiences language as an 'acoustic sensation' that 'provokes the stimulation, first, of his [sic] limbs, and then, of the phonatory organs' (Merleau-Ponty 1973: 14). For Merleau-Ponty, words are not 'inspected, analysed, known and constituted, but caught and taken up by a power of speech and, in the last analysis, by a motor power given to me along with the first experience I have of my body and its perceptual and practical field' (Merleau-Ponty 1976: 403). Merleau-Ponty also underscores the affective rather than the abstract nature of language. Of the word 'sleet', for example, he writes that the

word's meaning is not compounded of a certain number of physical characteristics belonging to the object; it is first and foremost the aspect taken on by the object in human experience, for example my wonder in the face of these hard, then friable, then melting pellets falling ready-made from the sky. (1976: 403) 
It is worth noting that Merleau-Ponty, like Damasio, deploys the language of poetry to describe our emotional relationship with the world.

Of course, language is not 'purely' a biological phenomenon. Neither are emotions 'pure' in a biological sense, given that the embodied mind emerges from a complex bio-cultural environment. Nevertheless, language must be understood in terms of the experience of a body perceiving and moving through the world. As George Lakoff and Mark Johnson argue in Philosophy in the Flesh: The Embodied Mind and its Challenge to Western Thought, language is enabled by not just the 'qualia' or feeling of being embodied in the world, but also by metaphorical ways of thinking and imagining that are literally 'shaped by the body' (Lakoff \& Johnson 1999: 6). These include what Lakoff and Johnson call container schema and source-path-goal schema, which are profoundly informed by our perception and movement.

Poiesis must also be understood in terms of the mind's embodiment. The argument that poetry is an intrinsically embodied and emotional form of expression is not new. Romantic and post-Romantic lyric verse understands itself and is generally understood as the expression of the 'felt I' that Damasio evokes as the experience of embodied consciousness. Poetry's attunement to 'the phenomenal materiality of language' (Schleifer 2009: 85), its textures and cadences, is also widely acknowledged. However, the emotionality that has been perceived as evidence of madness needs to be re-conceptualised as a natural experience of embodied cognition.

In fact, the feeling body might very well provide the source of the 'ineffable' that these poets often sought to articulate, as they mobilised embodied language techniques such as rhyme and rhythm - what the Romantic poet John Keats called the 'wings of Poesy' (Keats 1981 [1819]: 60) - in an attempt to communicate the unspeakable emotions of a body sensing the world through which it moves. In her study of Keats, Shahidha Bari describes the preeminence of feeling to Keats's work, evoking 'the peculiar phenomenality of Keats's poetry,' whereby feeling 'designates something that is non-conceptual, or not "known" ... but is "felt" as surely as it were' (Bari 2012: xvii). Keats himself referred to the emotional and generative experience of being immersed in 'uncertainties, Mysterious, doubts, without any irritable reaching after fact and reason' as 'Negative Capability' (Keats 1958: 193). In Toward a Theory of Cognitive Poetics, Reuven Tsur explicitly suggests that embodied and affective cognition, which he calls 'low-categorized information,' is what the Romantics mistook for the irrational and mystical source of their creativity (Tsur 1992: 21). [3]

Certainly my own experience of writing poetry is consistent with embodied theories of cognition and language use. I am 'moved' to write poetry as the result of a vital but indefinable feeling vis-à-vis a particular subject. I employ the rhythmic, moodful, associative, and resonant tools of poetic language to express that 'low-categorised' (Tsur 1992: 21) but nevertheless powerful information, which is the result of my body's interaction with the rich perceptual field of the world. It is an experience that is not confined to poets should such a category even exist, given that poets are also typically other things - much less 'mad' ones. Teenagers, teachers, hospitality workers, plasterers and gardeners can be moved to express their experience of being in the world, using the dynamic and enabling tool of verse.

To recognise the emotion from which poiesis arises is not to argue that poetry is informed by madness. Nor, importantly, is it to suggest that writing poetry simply entails channelling feeling. As Robert Weisberg argues, even if we agree that a lyric poem is invested in emotional communication, it is 'not an 
expression of emotion in exactly the same way as is a spontaneous change in facial expression' (Weisberg 1988: 256). A poem, in other words, is not a frown or a smile. In fact, poetry that aims for institutional recognition requires the poet to be culturally informed, self-reflexive, and engage in conscientious revision - of the kind that might even eventuate in a rejection of a Romantic emotionalism and lyricism viewed as passé, as we see in LANGUAGE poetry or some other ironic forms of postmodern verse. Nevertheless, such poetry merely strives for a different kind of 'affect' - one involving alienation, for example. Emotional engagement, which provides the substance of our cognitive responsiveness, is impossible to escape.

\section{Unstable cognition}

The second characteristic of the furor poeticus that I will redress via theories of embodied cognition is divergent thinking. There are a number of ways of conceptualising this cognitive phenomenon. Rothenberg, for instance, prefers the term 'Janusian,' which he describes as a cognitive attentiveness to contradictions and paradoxes (Rothenberg 1990: 16-17) and, moreover, an ability to conceive of those paradoxes as 'occupying the same space' (25). For Rothenberg, Janusian ideation is a 'prime factor in the production of poetic metaphors' (26). We might also think about divergent thinking in relation to defamiliarisation - the deliberate attempt to understand phenomena in a new way - as I suggested earlier. In effect, divergent thinking is flexible and novel thinking. However, divergent cognition viewed through the lens of psychopathology can become evidence of cognitive instability.

In another contemporary psychological study of creativity, Anger, Madness, and the Daimonic: The Psychological Genesis of Violence, Evil, and Creativity, Stephen Diamond theorises poiesis not only in relation to dramatic and violent emotion, but also in terms of a destructive potential associated with divergent ideation. Comparing the feminist poet Plath with the fascist dictator Adolf Hitler, and evoking the revolutionary poet Blake alongside the fictional villain Darth Vader, Diamond argues that there 'exists as close ... a correlation between anger, rage, and creativity as there does between anger, rage and evil' (Diamond 1996: 259). Diamond subscribes to an archetypal vision of mad poiesis, but rather than recklessly romanticising this phenomenon, he articulates a concern with how impassioned and atypical thinking can prove threatening towards cultural tradition and the status quo. He thus reveals himself as a disciple of Lombroso who, in The Criminal Man (2006 [1876]), defined the artist and, indeed, specifically the poet as a prime class of criminal.

The fact that contemporary psychological studies of creativity repeatedly rely on the same names - Plath and Blake being prominent among them - calls attention to the vast majority of sane poets that must be disregarded in order to make an argument for creative madness. The vision of the cognitively unstable and therefore socially threatening poet also overlooks the utterly conventional and marginal lives that most poets lead. Lady Caroline Lamb may have famously described Lord Byron - a poet self-consciously invested in 'dramatic posturing and exaggeration', as Schlesinger reminds us (2014: 68) - as 'mad, bad, and dangerous to know'. However, we need not fear poets or creative thinkers. In fact, cognitive science has demonstrated that flexible and creative cognition is an inevitable and necessary condition of the embodied mind rather than disturbing evidence of iconoclastic and antisocial behaviour.

As Armstrong points out, when it comes to creativity, the characteristic of originality has something of a checkered past. It has been alternatively 
undervalued or overvalued in our cultural history. To illustrate, Armstrong evokes the opposition between 'classical conceptions of art as balanced, rule governed, and symmetrical and Romantic valorisations of rule-breaking, original genius and idiosyncratic particularity' (Armstrong 2013: 13). Keeping in mind that 'what counts as harmony or dissonance is contingent and historically variable' (14), Armstrong argues that these diametrically opposed but nevertheless interdependent evaluations are striking for the ways in which they effectively parallel the nature of embodied cognition. They speak of what he describes as the brain's 'fixity and plasticity' (52).

Armstrong explains that the embodied brain, 'as a decentred, multidirectional ensemble of parallel-processing operations' (54), is made up of 'related, connected, but distinct and always somewhat disjunctive systems of information processing' (67). What this means is that there is no 'fixed' cognition; there is no pure, simple, and authoritative way of knowing. The brain derives information from visual, auditory and sensory spectrums, as well as from personal and cultural memory stores. It feels, and it simultaneously thinks. Even colour perception is not isolated, partaking of various sensory modalities in the embodied brain as well as of colour spectrums that are culturally differentiated. The brain is oriented to achieving fixity of cognition from that multi-dimensional informational flux in ways that engender movement. However, it can also very readily adjust perception and (e)motion as the earlier example of the misinterpreted snake-like stick in the grass demonstrates. Armstrong refers to the duck/rabbit image made famous by Ludwig Wittgenstein, and our shifting cognitive responses to this Janusian figure, in order to exemplify how the embodied brain attempts syntheses, but from a fundamental position of what he describes as 'stable instability' (77).

Notably, semi-stable perception of the duck or rabbit, and the uncanny awareness of underlying cognitive instability that the image generates, both elicit emotional gratification. In other words, as Armstrong argues, we are 'moved' towards cognitive certainty and uncertainty because our survival depends on our brains 'making neuronal connections and ... breaking their grip to enable new modes of cortical organization' (Armstrong 2013: 50). Given the neuro-culturally grounded nature of the human mind, one can be educated to be more inclined towards dissonance or harmony. This is apparent in the shifting preferences for cultural originality or conventionality outlined by Armstrong, but also in the different emotional responses to the duck/rabbit image, which can range from unhappy disorientation to glee. As Armstrong puts it, 'the brain can be habitualized, as the deterministic sceptics fear, but its patterns are more or less open to alteration, as the idealists hope' (120). However, 'the brain's ability to go back and forth between harmony and dissonance is evidence of a fundamental playfulness' (51).

This playfulness has been notably associated with creativity by psychoanalysts, including Freud, Jung and DW Winnicott, but there is nothing pathological about it (as Jung and Winnicott indeed reliably suggest). In fact, as the psychoanalyst Flaherty recognises - despite herself endorsing creativity's origins in emotional disorders - mental illness generally leads to 'inflexible thought' (Flaherty 2005: 66, my italics).

Contemporary theories of embodied cognition, which emphasise multidimensional processing and synaesthesiac bridging, obviously require a significant revision of Cartesian and ratiocentric understandings of identity and, indeed, of 'madness'. Without recourse to an adjudicating subjectivity or homunculus in the brain, Armstrong writes, the self can no longer be seen as a 'coherent, unified entity'; it must be reconceived as 'a process and an event' (Armstrong 2013: 126). Daniel Dennett, the iconoclastic philosopher of 
consciousness, similarly stresses that there simply is no 'thought-thinker ... with a determinate thought to be expressed' (Dennett 1991: 24). Thus cognition can be viewed as profoundly unstable, but this does not mean that we are all mad. What it does mean, for this paper at least, is that we can consider the cognitive play of poiesis as a productive repercussion of the flexibility of the embodied mind.

As Tsur puts it, if the Russian formalists advocated "'organized violence against cognitive processes" (Tsur 1992: 4), it was not because they had evil or unnatural designs to destroy the social order, but because thinking the world anew can be emotionally rewarding (12). Indeed, Victor Shklovsky's defence of defamiliarisation as a poetic technique is fascinating to reconsider in the light of embodied theories of cognition and the dialectic - itself Janusian between the brain's fixity and flexibility. In 'Art as Technique', Shklovsky argues that poets need to overcome automatic or fixed habits of perception; "to increase the difficulty and length of perception because the process of perception is an aesthetic end in itself and must be prolonged' (Shklovsky 1998 [1925]: 18). Shklovsky here recognises the ways in which perception is emotional and a reassessment of perception pleasurable. While our embodied brains 'move' us towards fixity, they also 'move' us towards cognitive flexibility. Indeed, as Shklovsky appreciates, fixity can be experienced as an un-generative and unhealthy rut. When the defamiliarising poet Charles Simic describes a fork as a 'strange thing' that 'must have crept / Right out of hell' (Simic 1995 [1959]: 34): readers are startled and reinvigorated into new ways of thinking about their world. Indeed, it is precisely that emotion of surprise and rejuvenation that I seek when I myself write de-familiarising poetry - an experience owing not to whatever psychopathology I may or may not have suffered, but to my brain's capacity for cognitive creativity.

\section{Unconscious cognition}

This final section of the paper will address what Rothenberg describes as the powerful 'mystique' of psychoanalytic theories that affirm the 'unconscious roots of creativity' (1990: 48). Rothenberg writes:

invoked more frequently in connection with creativity than with almost any other human action or experience, the unconscious is considered responsible for mysterious bolts from the blue, flashes of insight, waking from sleep with ideas already formed, and energy-releasing states of consciousness. Also, creative writings and works of art seem perfused with unconscious content such as Oedipus complexes, anima and animus, or sexual and aggressive symbolism. (Rothenberg 1990: 48)

The force of the unconscious, as Rothenberg suggests, is variously represented in the popular imagination in relation to creativity. Following Freud, for whom 'art is lined up with dreams, children's play, hysterical fantasies, neurotic symptoms, daydreaming, and masturbation' (Abella 2013: 58), creativity emerges from an unconscious figured as pleasure-seeking, reality-denying, unruly and conflicted. Alternatively and more positively, following Jung, creativity derives from universal archetypes lying dormant in the unconscious. There is also a more generic understanding of the unconscious, according to which it is simply the source of all that is mysterious. In all of these ways, however, the unconscious is revealed as integral to the myth of mad poiesis. 
Unconscious processes are indubitably involved in poiesis. In Patterns of Creativity: Investigations into the Sources and Methods of Creativity, Kevin Brophy memorably describes the process of composing a poem as akin to playing tennis in the fog (Brophy 2009: 38). The poet waits for phrases to enter her consciousness from the unconscious, like a player waiting for a ball to come flying out of impenetrable mist. However, as Brophy's benign and playful metaphor suggests, the unconscious need not be understood as the seat of madness. Indeed, cognitive science has demonstrated how non-conscious processes form a natural part of embodied cognition.

The brain, as Brophy observes, habitually 'works beyond consciousness' (90), with empirical studies showing how consciousness arrives half-a-second late. Brophy attributes the poet's 'experience of listening to a muse or receiving inspiration from a mysterious source' to this fact (90), but the ramifications of unconscious processing are of course much more comprehensive. Dennett makes the provocative claim that we are effectively zombies, with complex automatic systems controlling our cognition and movement. Such theories, as Dennett himself acknowledges, can generate hostility from those fearful of being diminished 'into mere protein robots' (Dennett 2005: 92). However, there is strong support within the cognitive sciences for understanding human beings, in the words of Damasio, as processes of 'nonconscious life management' (2012: 36), oriented towards a homeostasis brought about by emotional (chemical) incentives.

For Damasio, consciousness may contribute an enhanced attentional quality to cognitive processes. However, as I have suggested, he also believes that consciousness is fundamentally a 'feeling' of self-awareness; it is not 'the very thought of you' but the 'very felt thought of you' (Damasio 2012: 161). Damasio points out that it is possible to 'feel' conscious of all kinds of unconscious processes, from respiration to the motions involved in driving a vehicle, but such processes nevertheless occur wholly or largely unconsciously. As the example of driving suggests, our knowledge is fundamentally 'implicit, encrypted, and unconscious' (144) in ways that include culturally acquired skills. In fact, Damasio argues that human

childhood and adolescence take the inordinate amount of time that they do because it takes a long, long time to educate the nonconscious processes of our brain and to create, within that nonconscious brain space, a form of control that can, more or less faithfully, operate according to conscious intentions and goals. (270)

Damasio's bio-cultural view of embodied cognition means that part of our unconscious knowledge base, as Andy Clark points out in Being There: Putting Brain, Body and World Together Again, are 'the larger social and institutional structures in which the individual is embedded' (A Clark 1997: 182). These institutions are various and complex, providing new ways of thinking about ideology, for instance, but also about the culturally informed work of poiesis.

The cultural basis of creativity is not always given enough attention in psychoanalytic studies, which can espouse a kind of authentic and organic philosophy of artistic production. [4] However, art and poetry inevitably emerge from a cultural tradition, even if unconscious processes of embodied cognition can generate a kind of amnesia around the cultural enablers of the poet's praxis. In other words, poetry comes from the body but also from poetry, whether we are conscious of it or not. This is essentially the argument put forward by Timothy Clark, as canvassed earlier, according to which textuality might be viewed as self-generating - as well as generating its own mysterious 
creative aporia. It is an experience that rings true to my experience as a poet. I know, for instance, that the influence of Plath and Simic, which I have read obsessively at different times in my life, is apparent in my poetry, though I have never consciously emulated them at the time of composition. Nevertheless their gothic emotional landscapes and de-familiarised images are echoed in my own. At the same time, it should be noted that poets often self-consciously and playfully rewrite the work of their predecessors, paying homage or engaging in critical parody. When it comes to creativity the role of the unconscious, even when disassociated from madness, should not be overstated.

The Surrealists, of course, hailed the unconscious as the ultimate source of creativity. They engaged in various forms of proceduralist tactics - such as automatic writing and transcribing dreams - in order to lure out the madness within, which they identified with artistic genius. In his 1924 'Manifesto of Surrealism', Breton recalls the story of Saint-Pol-Roux who 'used to have a notice posted on the door of his manor house ... every evening before he went to sleep, which read: THE POET IS WORKING' (Breton 1972 [1924]: 14).

For Breton, however, the unconscious is fundamentally irrational and impolite, and therein lies its iconoclastic truth and beauty. Breton and the Surrealists, who rejected bourgeois rationality and conformity, who valorised the idiosyncratic and rebellious, were essentially post-Romantics. Their madness was political and aesthetic - as the cultural phenomenon of madness has always been.

One might continue to understand poetry as a contemplation of the unconscious, but only if we reconceptualise the unconscious as the fundamental bio-cultural condition of the embodied mind. Creativity cannot any longer be simplistically viewed, as per Freudian thinking, as 'a pathological functioning ... that ... carries out a defence against reality' on behalf of the unconscious (Abella 2013: 58), or as a way of tapping into Jungian wisdom stored unconsciously in the human mind. Grounded in unconscious processes of embodied cognition, creativity speaks of the unconscious in ways that illuminate much more than our allegedly hidden madness. Indeed, creativity can reveal what Damasio describes as the 'great subterraneum under our limited conscious existence' (2012: 175), the diverse bio-cultural knowledge base that 'has been part of the business of organizing life for a long, long time' but which is also always utterly contemporary.

\section{Conclusion}

In The Insanity Hoax: Exposing the Myth of the Mad Genius, Schlesinger writes: 'The mad genius is a beloved cultural artefact, a popular spectacle' (Schlesinger 2012: 171). However, she argues that 'there is simply no good reason to believe that exceptionally creative people are more afflicted with psychopathology than anyone else' (171). There are novelists, artists, playwrights and poets with psychological problems, she continues, 'just as there are erratic and unhappy lawyers and librarians, teachers and telemarketers' (12).

As Ellen Dissanayake suggests - in a sociobiological study of creativity founded in embodied and emotional expression - if poiesis continues to be viewed as mad today it must be partly due to the 'anomalous' pursuit of such an un-lucrative but time-consuming activity in a capitalist world in which 'expanding profits ... and cost-effectiveness are valued above everything' (Dissanayake 2000: 170). The interpretation is Foucauldian. Of course, it is precisely in such a ratiocentric context that the mad poet has currency and can 
be fetishised. This paper does not deny that those commonly fetishised traits of poiesis - emotionalism, divergent thinking, and the unconscious - inform creativity. Rather, it re-envisions these experiences as both ordinary and complex features of embodied cognition. As I have argued, embodied cognition is fundamentally emotional, with language forming part of the affective reality of our lives. Embodied cognition is also dynamic and creative, as well as being reliant on unconscious bio-cultural knowledge. It is not madness but the bioculturally embodied mind that ultimately underlies poetic creativity. As Mark Turner argues, the 'literary mind is not a separate kind of mind. It is our mind. The literary mind is the fundamental mind' (Turner 1996: v).

\section{Notes}

[1] Michel Foucault nevertheless remains invested in a fetishised vision of madness that lies beyond Enlightenment interpretations and what he describes as psychoanalysis's 'monologue of reason' (Foucault 1989: xii). This transcendent vision of madness is notably bound up with the arts. While Foucault argues that 'madness is precisely the absence of the work of art,' 'the point where it becomes impossible and where it must fall silent' (270), art is nevertheless theorised as being in a perilous and uncanny dialogue with that inscrutable condition. Foucault's case studies are conspicuously selective: the work of Goya, Bosch, Brueghel, Nietzsche, Artaud and de Sade. return to text

[2] Contemporary psychological studies typically define creativity in terms of lists of cognitive qualities, but I am not interested in reprising or engaging with those variously articulated criteria. My interest is in the 'mad poet' and the associated characteristics typically attributed to the furor poeticus as a cultural phenomenon. This cultural phenomenon is inevitably informed by ancient thought, Romantic or post-Romantic philosophy, psychoanalysis and psychology. Certainly, the qualities of intense emotionality and divergent thinking chime with common psychological criteria for creativity. return to text

[3] The emotional knowledge of the body might also be seen to explain Foucault's ecstatic vision of madness. return to text

[4] Take Harold Blum's reading of Picasso's creativity in the Blue Period, for instance, in terms of the artist's 'prolonged adolescent separation and individuation process, his developmental challenges, unconscious conflicts and trauma' (Blum 2013: 30). return to text

\section{Works Cited}

Abella, A 2013 'Psychoanalysis and Art: From Applied Analysis to Interdisciplinary Dialogue', in G Goldstein (ed) Art in Psychoanalysis: A Contemporary Approach to Creativity and Analytic Practice, Karnac, London: 57-77 return to text

Armstrong, P 2013 How Literature Plays with the Brain: The Neuroscience of Reading and Art, Johns Hopkins University Press, Baltimore MD return to text

Bari, S 2012 Keats and Philosophy: The Life of Sensations, Routledge, New York return to text

Blum, HP 2013 'Picasso's Prolonged Adolescence, his Blue Period, and Blind Figures', in G Goldstein (ed) Art in Psychoanalysis: A Contemporary Approach to Creativity and Analytic Practice, Karnac, London: 39-55 return to text

Breton, A 1972 'Manifesto of Surrealism (1924)', in Manifestoes of Surrealism, trans R Seaver \& HR Lane, The University of Michigan, Ann Arbor: 3-47 return to text

Brophy, K 2009 Patterns of Creativity: Investigations into the Sources and Methods of Creativity, Rodopi, Amsterdam return to text

Burwick, F 1996 Poetic Madness and the Romantic Imagination, Pennsylvania State University Press, University Park PA return to text 
Clark, A 1997 Being There: Putting Brain, Body and World Together Again, MIT Press, Cambridge MA return to text

Clark, T 1997 The Theory of Inspiration: Composition as a Crisis of Subjectivity in Romantic and Post-Romantic Writing, Manchester University Press, Manchester return to text

Damasio, A 2012 Self Comes to Mind: Constructing the Conscious Brain, Vintage, London return to text

Dennett, D 2005 Sweet Dreams: Philosophical Obstacles to a Science of Consciousness, MIT Press, Cambridge MA return to text

Dennett, D 1991 Consciousness Explained, Little, Brown, Boston return to text

Diamond, S 1996 Anger, Madness, and the Daimonic: The Psychological Genesis of Violence, Evil, and Creativity, State University of New York Press, Albany NY return to text

Dissanayake, E 2000 Art and Intimacy: How the Arts Began, University of Washington Press, Seattle WA return to text

Feldman, JA 2006 From Molecule to Metaphor: A Neural Theory of Language, MIT Press, Cambridge MA return to text

Flaherty, A 2005 The Midnight Disease: The Drive to Write, Writer's Block, and the Creative Brain, Houghton Mifflin, New York return to text

Foucault, M 1989 [1961] Madness and Civilization: A History of Insanity in the Age of Reason, trans R Howard, Routledge, London return to text

Glenberg, AM 2008 'Toward the Integration of Bodily States, Language and Action', in GR Semin \& ER Smith (eds) Embodied Grounding: Social, Cognitive, Affective and Neuroscientific Approaches, Cambridge University Press, New York: 43-70 return to text

Horton, SS (ed) 2014 Affective Disorder and the Writing Life: The Melancholic Muse, Palgrave Macmillan, Houndmills Hampshire return to text

Keats, J 1981 [1819] 'Ode to a Nightingale', The Complete Poems, Penguin, Harmondsworth: $346-8$ return to text

Keats, J 1958 The Letters of John Keats, vol 1, Cambridge University Press, Cambridge return to text

Kyaga, S 2015 Creativity and Mental Illness: The Mad Genius in Question, Palgrave Macmillan, Houndmills Hampshire return to text

Lakoff, G \& M Johnson 1999 Philosophy in the Flesh: The Embodied Mind and its Challenge to Western Thought, Basic Books, New York return to text

Lombroso, C 2006 [1876] Criminal Man, trans M Gibson \& NH Rafter, Duke University Press, Durham NC return to text

Lombroso, C 1984 [1895] The Man of Genius, Garland Publishing, New York return to text

Merleau-Ponty, M 1976 Phenomenology of Perception, trans C Smith, Routledge \& Kegan Paul, London return to text

Merleau-Ponty, M 1973 Consciousness and the Acquisition of Language, trans HJ Silverman, Northwestern University Press, Evanston IL return to text

Moffitt, J 2005 Inspiration: Bacchus and the Cultural History of a Creation Myth, Brill, Leiden return to text

Nettle, D 2001 Strong Imagination: Madness, Creativity, and Human Nature, Oxford University Press, Oxford return to text

Porter, R 1987 'Bedlam and Parnassus: Mad People's Writing in Georgian England', in G Levine (ed) One Culture: Essays in Science and Literature, University of Wisconsin Press, Madison WI: $258-84$ return to text 
Rothenberg, A 1990 Creativity and Madness: New Findings and Old Stereotypes, Johns Hopkins University Press, Baltimore MD return to text

Schleifer, R 2009 Intangible Materialism: The Body, Scientific Knowledge, and the Power of Language, University of Minnesota Press, Minneapolis return to text

Schlesinger, J 2014 'Building Connections on Sand: The Cautionary Chapter', in JC Kaufman (ed) Creativity and Mental Illness, Cambridge University Press, Cambridge: 60-75 return to text

Schlesinger, J 2012 The Insanity Hoax: Exposing the Myth of the Mad Genius, Shrinktunes Media, Ardlsey-on-Hudson NY return to text

Shklovsky, V 1998 [1925] 'Art as Technique', in J Rivkin \& M Ryan (eds) Literary Theory: An Anthology, Blackwell, Malden MA: 17-23 return to text

Simic, C 1995 [1959] 'Fork', Selected Poems 1963-1983, George Braziller, New York: 34 return to text

Tsur, R 1992 Toward a Theory of Cognitive Poetics, North Holland, Amsterdam return to text

Turner, M 1996 The Literary Mind, Oxford University Press, New York return to text

Varela, F, E Thompson \& E Rosch 1997 The Embodied Mind: Cognitive Science and Human Experience, MIT Press, Cambridge MA return to text

Weisberg, R 1988 'Problem Solving and Creativity', in RJ Sternberg (ed) The Nature of Creativity: Contemporary Psychological Perspectives, Cambridge University Press, Cambridge: $148-76$ return to text

Dr Maria Takolander is an Associate Professor in Professional and Creative Writing and Literary Studies at Deakin University in Geelong, Victoria. She is the author of a collection of short stories, The Double (Text 2013); three books of poetry, The End of the World (Giramondo 2014), Ghostly Subjects (Salt 2009), and Narcissism (Whitmore Press 2005); and a book of literary criticism, Catching Butterflies: Bringing Magical Realism to Ground (Peter Lang 2007). Her recently published research has investigated poiesis using cognitivescience paradigms.

\section{TEXT}

Vol 19 No 2 October 2015

http://www.textjournal.com.au

General Editor: Nigel Krauth. Editors: Kevin Brophy \& Enza Gandolfo text@textjournal.com.au 